\title{
Sosialisasi Cara Budidaya Ikan yang Baik sebagai Manajemen Pengendali Mutu Budidaya Ikan di Desa Tanjung Seri Kecamatan Laut Tador Kabupaten Batu Bara
}

\author{
Ria Retno
}

Universitas HKBP Nommensen Pematangsiantar, Indonesia

\begin{abstract}
Cara budidaya ikan yang baik (CBIB) adalah cara memelihara dan/atau membesar kan ikan serta memanen hasilnya dalam lingkungan yang terkontrol shg memberikan jaminan keamanan pangan dari pembudidayaan dengan memperhatikan sanitasi, obat ikan, pakan dan bahan kimia serta biologis. Sosialisasi CBIB bertujuan agar masyarakat pembudidaya ikan di Desa Tanjung Seri Kabupaten Batu Bara dapat memanajemen budidaya ikan dengan baik, terkhususnya budidaya ikan lele dengan cara terkontrol dengan memperhatikan sanitasi, obat ikan, pakan dan bahan kimia serta biologis. Metode yang digunakan adalah metode presentasi. Sosialisasi tentang cara budidaya ikan yang baik ini sangat bermanfaat terhadap kelompok pembudidaya ikan, hal ini terbukti dari semangat warga yang cukup antusias dalam mengikuti sosialisasi mulai dari awal sampai akhir.
\end{abstract}

Keywords: Sosialisasi, CBIB, Tanjung Seri.

\section{Pendahuluan}

Ikan lele (Clarias sp.) termasuk salah satu dari keenam komoditas lainnya yaitu, rumput laut, patin, bandeng, nila, dan kerapu yang akan dipacu pengembangan budidayanya dengan tujuan meningkatkan produksi budidaya pada beberapa tahun kedepan (Riyanto et al., 2010). Manajemen adalah sebuah proses yang dilakukan untuk mewujudkan tujuan organisasi melalui serangkaian kegiatan berupa perencanaan, pengorganisasian, pengarahan dan pengendalian orangorang serta sumber daya organisasi lainnya (Sartika, 2020). Cara budidaya ikan yang baik (CBIB) adalah cara memelihara dan/atau membesar kan ikan serta memanen hasilnya dalam lingkungan yang terkontrol shg memberikan jaminan keamanan pangan dari pembudidayaan dengan memperhatikan sanitasi, obat ikan, pakan dan bahan kimia serta biologis (KKP, 2007).

Indonesia sebagai Negara yang secara signifikan menjadi penghasil perikanan budidaya di dunia sehingga perlu dikawal dengan petunjuk dan sistem yang kuat agar secara efisien dapat menghasilkan ikan yang berkualitas dalam skala usaha masyarakat dengan tingkat kepastian iklim usaha yang tinggi. Indonesia memiliki potensi lahan budidaya air tawar $\pm 2,2$ juta ha. Angka ini benar-benar menjadi peluang besar untuk masyarakat pembudidaya ikan air tawar dalam mengembangkan dan meningkatkan produksi budidaya (KKP, 2014). Pengembangan sector perikanan merupakan suatu Prime Mover yang dimanfaatkan dalam mengatasi krisis ekonomi menuju Indonesia maju dan makmur (Sutarjo \& Samsundari, 2018).

\footnotetext{
* Corresponding author:

E-mail address: riaretnomanik@gmail.com
} 
Kementerian Kelautan dan Perikanan Republik Indonesia mengeluarkan Keputusan Menteri Kelautan dan Perikanan Republik Indonesia Nomor KEP.02/MEN/2007 tentang cara budidaya ikan yang baik (CBIB) dengan maksud untuk mengatur kegiatan pembudidayaan ikan bagi pembudidaya agar menerapkan CBIB seperti memberikan acuan secara teknis sebagai persyaratan yang harus diperhatikan dengan baik dan benar bagi Auditor cbib, kelompok budidaya ikan dan pelaku usaha lainnya.

Sosialisasi CBIB bertujuan agar masyarakat pembudidaya ikan di Desa Tanjung Seri Kabupaten Batu Bara dapat memanajemen budidaya ikan dengan baik, terkhususnya budidaya ikan lele dengan cara terkontrol dengan memperhatikan sanitasi, obat ikan, pakan dan bahan kimia serta biologis. Pembudidaya ikan lele selama ini hanya memperhatikan pertumbuhan dari ikan lele tanpa memperhatikan sanitasi dan standar penggunaan obat-obatan dan pakan.

\section{Metode}

Pelaksanaan sosialisasi dilakukan kepada kelompok pembudidaya ikan di Desa Tanjung Seri Kecamatan Laut Tador Kabupaten Batu Bara. Sosialisasi dilakukan dalam 2 tahapan yaitu perencanaan dan pelaksanaan, dengan kurun waktu kurang lebih 1 bulan. Kegiatan sosialisasi dilaksanakan di Unit Pembenihan Rakyat Ma'arif milik kelompok pembudidaya ikan Desa Tanjung Seri Kecamatan Laut Tador pada hari Jumat, 23 Oktober 2020 yang diikuti oleh 20 peserta.

\section{Pembahasan}

Pedoman Cara Budidaya Ikan Yang Baik

\subsection{Lokasi}

Lokasi budidaya harus tidak menimbulkan bahaya keamanan pangan, akibat kondisi sekitar, baik air pasok maupun pencemaran udara.

\subsection{Suplai air}

Air pasok (suplai air) untuk budidaya harus tidak menimbulkan bahaya keamanan pangan.

a) Lokasi dekat dengan sungai dan mempunyai akses yang mudah untuk kecukupan air yang berkualitas sepanjang tahun;

b) Tidak ada endapan lumpur budidaya yang dibuang ke perairan alam, termasuk dari unit usaha;

c) Endapan lumpur dibuang dengan saluran terpisah dan aman untuk menghindari polusi dari dalam (selfpollution);

d) Air limbah tidak digunakan untuk budidaya;

e) Mempunyai tindakan pengelolaan (contoh: tandon penampungan) untuk meningkatkan/ perlakuan air masuk.

3.3 Tata Letak dan Desain

a) Area usaha budidaya hanya digunakan untuk pembudidayaan ikan

b) Unit usaha budidaya mempunyai desain \& tata letak yang dapat mencegah kontaminasi silang

c) Toilet, septic tank, gudang dan fasilitas lainnya terpisah dan tidak berpotensi mengontaminasi produk budidaya

d) Unit budidaya memiliki fasilitas pembuangan limbah cair/padat yang di area yang sesuai

3.4 Kebersihan Fasilitas dan Perlengkapan

a) Unit usaha budidaya dan lingkungannya dijaga kondisi kebersihan dan higienis

b) Dilakukan tindakan pencegahan terhadap binatang \& hama penyebab kontaminasi 
c) BBM, bahan kimia (desinfektan, pupuk, reagen), pakan dan obat ikan disimpan dalam tempat yang terpisah dan aman.

d) Wadah, perlengkapan \& fasilitas budidaya dibuat dari bahan yg tidak menyebabkan kontaminasi.

e) Fasilitas \& perlengkapan dijaga dalam kondisi higienis \& dibersihkan sebelum dan sesudah digunakan; serta (bila perlu) didesinfeksi dengan desinfektan yg diizinkan

3.5 Persiapan Wadah untuk Penebaran Benih

a) Wadah budidaya dipersiapkan dengan baik sebelum penebaran benih

b) Dalam persiapan wadah dan air, hanya menggunakan pupuk, probiotik dan bahan kimia yang direkomendasikan.

3.6 Pengelolaan Air

a) Dilakukan filtrasi air atau pengendapan serta menja-min kualitas air sesuai untuk ikan dibudidayakan

b) Monitor kualitas air sumber secara rutin untuk menjamin kesehatan dan kebersihan ikan yang dibudidayakan

3.7 Benih

Benih sehat bersertifikat berasal dari hatchery yang bersertifikat dan atau memiliki sertifikat bebas penyakit dan obat ikan.

\subsection{Pakan}

a) Pakan Ikan yang digunakan memiliki nomor pendaftaran/ sertifikat yang dikeluarkan Direktur Jenderal atau surat jaminan dari institusi yang berkompeten

b) Pakan ikan disimpan dengan baik dalam ruangan yang kering dan sejuk untuk menjaga kualitas mutu serta digunakakan sebelum masa kadaluwarsanya.

c) Pakan tidak dicampur bahan tambahan seperti antibiotik, obat ikan, bahan kimia lainnya atau hormon yang dilarang

d) Pakan buatan sendiri harus dibuat dari bahan yang direko-mendasikan dan tidak dicampur dengan bahanbahan terlarang

e) Pemberian pakan dilakukan dengan cara yang efisien mengikuti ratio pemberian yang dianjurkan

f) Pakan berlabel/memiliki informasi yang mencantumkan komposisi, tanggal daluwarsa, dosis dan cara pemberian dengan jelas

3.9 Obat Ikan, Bahan Kimia Dan Substansi Berbahaya

a) Hanya menggunakan obat ikan, bahan kimia dan biologis yang diijinkan (registrasi dari DJPB)

b) Obat ikan yang diijinkan digunakan sesuai petunjuk dan pengawasan

c) Obat ikan, bahan kimia dan biologis disimpan dengan baik sesuai spesifikasi

3.10 Penggunaan Es dan Air

a) Air bersih tersedia dalam jumlah yang cukup untuk panen, penanganan dan proses pencucian

b) Es hanya berasal dari pemasok yang direkomendasi dan menggunakan air bersih

c) Es diterima dalam kondisi saniter

\subsection{Pemanenan}

a) Perlengkapan dan peralatan mudah dibersihkan dan dijaga dalam kondisi bersih dan higienis

b) Panen dipersiapkan dengan baik untuk hindari pengaruh temperatur tinggi pada ikan

c) Pada saat panen dilakukan upaya untuk menghindari terjadinya penurunan mutu dan kontaminasi ikan

d) Penanganan ikan dilakukan secara higienis dan efisien sehingga tidak menimbulkan kerusakan fisik 


\subsection{Penanganan Hasil}

a) Peralatan dan perlengkapan untuk penanganan hasil mudah dibersihkan dan didesinfeksi (bila perlu) serta selalu dijaga dalam keadaan bersih

b) Ikan mati segera didinginkan dan diupayakan suhunya mendekati $0^{\circ} \mathrm{C}$ di seluruh bagian.

c) Proses penanganan (sortir, penimbangan, pencucian, pembilasan, dll) dilakukan dengan cepat dan higienis tanpa merusak produk.

d) Berdasarkan persyaratan yang berlaku, bahan tambahan \& kimia yang dilarang tidak digunakan pada ikan, yang diangkut dalam kondisi mati atau hidup)

3.13 Pengangkutan

a) Peralatan dan fasilitas pengangkutan yang digunakan mudah dibersihkan dan selalu terjaga kebersihannya (boks, wadah, dan lain-lain)

b) Pengangkutan dalam kondisi higienis untuk menghindari kontaminasi sekitar (seperti udara, tanah, air, oli, bahan kimia) dan kontaminasi silang.

c) Suhu produk selama pengangkutan mendekati suhu cair es $\left(0^{\circ} \mathrm{C}\right)$ pada seluruh bagian produk

\subsection{Pengolahan Limbah}

Limbah (cair, padat dan bahaya) dikelola dengan cara yang higienis dan saniter untuk mencegah kontaminasi.

\subsection{Pencatatan}

a) Dilakukan rekaman pada jenis dan asal pakan (pakan pabrikan) serta bahan baku pakan ikan (untuk pakan buatan sendiri).

b) Penyimpanan rekaman penggunaan obat ikan, bahan kimia dan bahan biologi atau perlakuan lain selama masa pemeliharaan

c) Penyimpanan rekaman kualitas air (air sumber, air pasok, air pemeliharaan dan limbah cair) sesuai kebutuhan

d) Penyimpanan rekaman kejadian penyakit yang mungkin berdampak pada keamanan pangan produk perikanan

e) Rekaman panen disimpan dengan baik

f) Catatan/ Rekaman pengangkutan Ikan disimpan dengan baik

\subsection{Tindakan Perbaikan}

Tindakan perbaikan (atas bahaya kemanan pangan) dilakukan sebagai kegiatan yang rutin dan terkendali.

\subsection{Pelatihan}

Pemilik unit usaha atau pekerja sadar dan terlatih (pelatihan, seminar, workshop, sosialisasi, dsb) dalam mencegah dan mengendalikan bahaya keamanan pangan dalam perikanan budidaya.

\subsection{Kesehatan dan Higienis Personal}

Pekerja yang menangani ikan dalam kondisi sehat. 

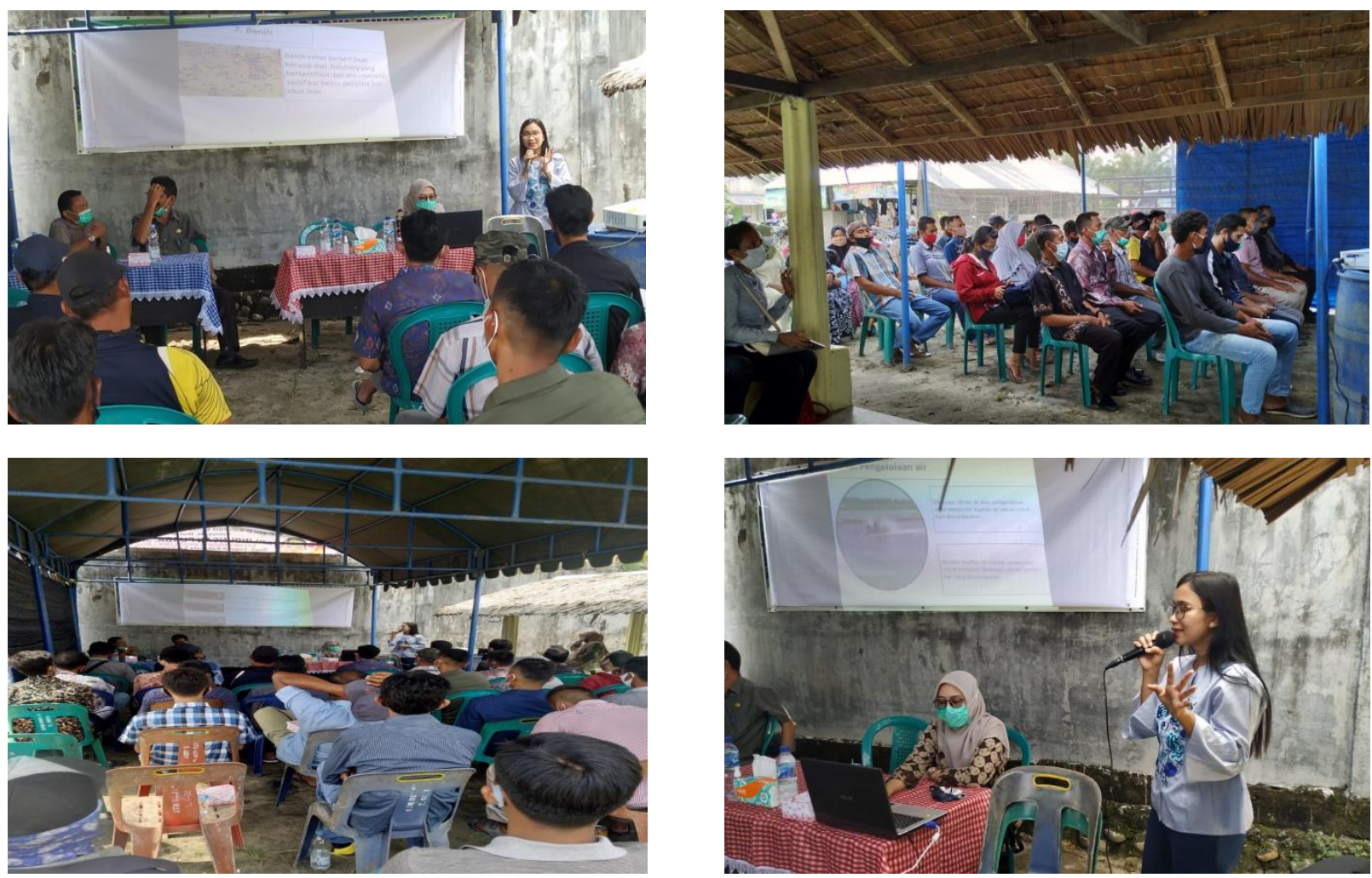

Fig. 1. Kegiatan Sosialisasi Cara Budidaya Ikan yang Baik

Respon peserta saat pelaksanaan pelatihan sangat baik dan seluruh peserta begitu antusias memperhatikan setiap penjelasan. Dari 20 peserta, ada 2 orang yang mengajukan pertanyaan. Penanya pertama, bertanya tentang cara mengetahui bagaimana membeli benih yang mempunyai sertifikat, penanya kedua bertanya tentang bagaimana cara mengetahui penggunaan obat ikan yang diperbolehkan dan yang tidak diperbolehkan.

\section{Kesimpulan}

Sosialisasi tentang cara budidaya ikan yang baik sebagai manajemen pengendali mutu budidaya ikan di Desa Tanjung Seri Kecamatan Laut Tador Kabupaten Batu Bara ini sangat bermanfaat terhadap kelompok pembudidaya ikan, hal ini terbukti dari semangat warga yang cukup antusias dalam mengikuti sosialisasi mulai dari awal sampai akhir.

\section{Acknowledgements}

Kami mengucapkan terima kasih kepada Dinas Perikanan Kabupaten Batu Bara dan kepada kelompok masyarakat pembudidaya ikan Desa Tanjung Seri Kecamatan Laut Tador yang turut terlibat secara langsung dalam mensukseskan kegiatan program pengabdian masyarakat.

\section{References}

KKP (Kementerian Kelautan dan Perikanan). (2007). Keputusan Menteri Kelautan dan Perikanan Republik Indonesia Nomor KEP.02/MEN/2007 tentang Cara Budidaya Ikan yang Baik. 
KKP (Kementerian Kelautan dan Perikanan). (2014). Perikanan Budidaya Indonesia. Direktorat Jenderal Perikanan Budidaya.

Manik, R. R. D. S. (2020). Dasar-dasar Manajemen. Bandung: Widina Bhakti Persada Bandung

Riyanto, S., Padang. W.I., \& Peni. (2010). Tabloid Agrina. Vol. 5, No.122.

Sutarjo, G. A., \& Samsundari, S. (2018). Peningkatan produksi budidaya ikan air tawar melalui penerapan manajemen kualitas air dan pembuatan pakan ikan mandiri di kelompok pembudidaya ikan "sumber rejeki" dan "cinta alam" kecamatan bungatan kabupaten situbondo. Jurnal Dedikasi, 15(1), 1-4. 